\title{
Rat Subcutaneous Tissue Response to Modified Portland Cement, a New Mineral Trioxide Aggregate
}

\author{
Ricardo MARTÍNEZ LALIS \\ María Laura ESAÍN \\ Gabriel A. KOKUBU \\ Julia WILLIS \\ Carolina CHAVES \\ Daniel R. GRANA \\ Dental School, University del Salvador, Buenos Aires, Argentina; \\ Dental Association of Argentina, Buenos Aires, Argentina
}

\begin{abstract}
The purpose of this study was compare the biocompatibility of modified Portland cement (CPM) and mineral trioxide aggregate (MTA) in a subcutaneous rat model. Twenty-four male Wistar rats were used. Three silicon tubes were placed on the dorsal subcutaneous tissue of each animal: one tube contained MTA, one tube contained CPM and the other was an empty tube. The rats were sacrificed in 3 groups of 8 animals at 7, 14 and 30 postoperative days, respectively. Tissue samples were fixed in 10\% buffered formalin, embedded in paraffin, and serial sections were cut and stained with hematoxylin and eosin, Masson Trichrome and Luna's stain. At day 7, the empty tubes displayed a mild inflammatory infiltrate. In the CPM group, an inflammatory infiltrate was observed with some eosinophils and immature connective tissue. The MTA group showed a similar infiltrate without eosinophils and presence of abundant necrotic tissue and numerous multinucleate foreign body giant cells. At day 14, the chronic infiltrate with eosinophils persisted when in contact with CPM. In the MTA group, necrosis and distant giant cells could still be seen. At day 30, all 3 groups showed mature fibrous collagenous tissue. These findings indicate a different response to the materials evaluated in this study. Although, MTA and CPM induced a chronic inflammatory infiltrate, necrosis and multinucleated foreign body giant cells predominated in the MTA group, while in the CPM group numerous eosinophils were seen at all the observational periods.
\end{abstract}

Key Words: biocompatibility, modified Portland cement, endodontics, mineral trioxide aggregate.

\section{INTRODUCTION}

The aim of the endodontic treatment is to clean, disinfect and seal the root canal system. Nevertheless, in some cases, due to the complex anatomy or iatrogenic procedures, it is not possible to reach this goal (1). In some cases, treatment failure is solved by endodontic surgery. Periapical surgery usually consists of apicoectomy, apical cavity preparation and root-end filling to seal the communication pathways between the root canal system and periapical tissues. For a long time, the materials of choice for this procedure have been amalgam, IRM, Super-EBA and glass ionomer cements. However, these materials have the disadvantage of undergoing corrosion, electrolysis, delayed expansion and staining (amalgam), marginal leakage, moisture sensitivity and toxicity for vital tissues (2).

Mineral trioxide aggregate (MTA) has been developed to reduce some of these shortcomings. MTA also stimulates hard and soft tissue repair in the periradicular tissues (3). MTA is composed of calcium oxide and silicon dioxide, which, together correspond to $70-95 \%$ of the cement. The mixture of these components produces tricalcium silicate, dicalcium silicate, tricalcium aluminate and tetracalcium aluminoferrite. Bismuth oxide is added as a radiopacifier (4). The powder con- 
sists of fine hydrophilic particles that form a colloidal gel in the presence of moisture. MTA has an initial $\mathrm{pH}$ of 10.2 soon after mixture with water, which increases to approximately 12.5 after $3 \mathrm{~h}$ and then remains stable for prolonged time. The solidification of the gel makes a very hard structure that reaches a high compressive strength alter 21 days (45 MPa) (5).

Camilleri et al. (6) have demonstrated that both Portland cement (PC) and MTA are composed of tricalcium and dicalcium silicate, which, upon hydration, produce calcium silicate hydrate gel and calcium hydroxide. Aged material may not be as biocompatible as freshly mixed material due to the amount of calcium hydroxide produced during the hydration reaction (6). Both MTA and the PC have similar composition, except for the presence of bismuth compounds in MTA (6). MTA has less gypsum and a more uniform and smaller particle size compared to PC (4).

Root-end filling and sealing materials must fulfill different stability, solubility, sealing ability requirements (5). However, biocompatibility is one of the most important factors when choosing a material in order to prevent any adverse reaction that might induce endodontic treatment failure (7). Recently, a material with similar chemical characteristics to MTA, the modified Portland cement (CPM), has been introduced to the market. According to the manufacturer's website (8), CPM is a mineral trioxide with addition of calcium carbonate, silicon dioxide, bismuth trioxide and barium sulphate. Although there is an extended body of knowledge on MTA biocompatibility (3,9-11), as far as it could be ascertained, no study has yet investigated the biological properties of CPM. Thus, the purpose of this study was to compare the biocompatibility of CPM and MTA in rat subcutaneous connective tissue.

\section{MATERIAL AND METHODS}

The research project was independently reviewed and approved by Research Ethics Committee of the Dental Association of Argentina. Animals were handled and maintained in accordance with international recommendations (12).

Twenty-four male Wistar (Rattus norvegicus albinus) rats aged 3 to 4 months and weighing between 250 and $300 \mathrm{~g}$ were used. The animals were housed at the School of Medicine of University del Salvador under climate-controlled conditions (12 h light/12 h dark cycles and thermostatically regulated room temperature) and were fed a commercial chow (Cooperación, Buenos Aires, Argentina) and water ad libitum.

MTA (ProRoot; Dentsply Tulsa Dental, OK, USA) and CPM (Laboratorio Egeo, Buenos Aires, Argentina) were prepared following manufacturers' instructions under aseptic conditions. Autoclaved silicone tubes ( $5 \mathrm{~mm}$ long and $1 \mathrm{~mm}$ inner diameter) were filled with the materials with the aid of digital pluggers (Boers \#70; Dentsply/Maillefer, Ballaigues, Switzerland). Under dissociative anesthesia - ketamine chloride $(14 \mathrm{mg} / \mathrm{kg}$ body weight) and acepromazine ( $10 \mathrm{mg} / \mathrm{kg}$ body weight) intraperitoneally - and aseptic conditions, 3 silicone tubes were implanted into the subcutaneous connective tissue of each rat. The implantation procedure was as follows. The dorsal skin was shaved and disinfected with a polyvinylpyrrolidone-iodine solution (Pervinox; Laboratorio Phoenix, Buenos Aires, Argentina) and 2 approximately 15 -mm-long incisions were made using a scalpel. By blunt dissection, 3 pockets were prepared and received one silicone tube filled with MTA, another one filled with CPM and a third empty tube that served as a control. The implants were carefully placed into the pockets to a depth of $20 \mathrm{~mm}$ from the line of incision to avoid that tissue response to one material interred to the other. Care was taken to prevent smearing of the test material on the lateral sides of the tubes. Finally, the wounds were closed with cyanoacrylate ester adhesive (La Gotita; Akapol S.A., Buenos Aires, Argentina).

The rats were killed by anesthetic overdose in groups of 8 animals 7, 14, and 30 days after implantation. The tissue samples were fixed in $10 \%$ buffered formalin, subjected to routine histological processing and embedded in paraffin. The paraffin blocks were oriented parallel to the tube long axis and approximately $7-\mu \mathrm{m}$-thick serial longitudinal sections were obtained from the central portion of each tube, and stained with hematoxylin and eosin and Masson's Trichrome. Luna's staining for eosinophils was done to confirm the obtained results (13).

Two independent examiners evaluated the specimens in a blind fashion. In order to estimate the tissue response in the areas adjacent to the tube ends, 3 sections belonging to the central areas of each specimen were analyzed at different magnifications with a light microscope (Ultraphot; Carl Zeiss, Oberkochen, Germany) equipped with a digital camera (Canon Powershot A510; Canon, Tokyo, Japan). The sections were examined for 
presence of vascular alterations, inflammatory infiltrate and fibrous capsule thickness, the latter being measured with Image Pro Plus for Windows, v. 4.5 image-analysis software (Media Cybernetics, Silver Spring, MD, USA).

The occurrence of chronic inflammatory infiltrate composed of macrophages, lymphocytes and plasmocytes, as well as the presence of eosinophils and multinucleate foreign body giant cells was evaluated at all evaluation periods. These inflammatory responses were scored semi-quantitatively according to the following criteria: 0 (no reaction): absence of inflammatory cells; + (mild reaction): presence of mild chronic inflammatory infiltrate, or few eosinophils or giant cells; ++ (moderate reaction): presence of moderate chronic inflammatory infiltrate, or some eosinophils or giant cells, or +++ (severe reaction): presence of an intense chronic inflammatory infiltrate, large number of eosinophils or giant cells. The thickness of the fibrous capsule formed around the implanted materials was also measured at all evaluation periods.

Discontinuous data were analyzed statistically by non-parametric ANOVA, while quantitative data were evaluated by one-way ANOVA. The significance level was set at 5\% for all analyses.

\section{RESULTS}

Macroscopic examination at the implant sites revealed that wound healing was satisfactory and without infection at all evaluation periods. The severity of tissue reaction to the implanted materials is shown in Table 1. The thickness of the fibrous capsule formed around the implanted materials at the different evaluation periods is presented in Table 2 .

Mild chronic infiltrate was observed in all groups after 7 and 14 days, although the control group (empty tubes) showed few inflammatory cells. At day 30, all groups presented a mature fibro-collagen tissue. No eosinophils were seen in the control group throughout the study. Scarce eosinophils were seen in the MTA group at days 7 and 14, while the CPM group showed numerous eosinophils at all observation periods ( $p<0.001$ at 7 and 30 days; $p<0.05$ at 14 days) (Fig. 1 ).

The presence of giant cells was notorious in the MTA group after 7 and 14 days, with a statistically significant difference $(\mathrm{p}=0.0002)$ from the CPM group (Fig. 2). In the MTA group, wide areas of necrotic tissue could be observed, in some cases reaching the subcutaneous muscular tissue.

The immature fibrous tissue seen at day 7 evolved to a mature fibrous capsule at 30 days. The control group (empty tube) had the thinnest $(p<0.001)$ fibrous capsule formed around the implanted materials (Table 2).
Table 2. Thickness (in $\mu \mathrm{m}$ ) of the fibrous capsule formed around the implanted materials.

\begin{tabular}{cccc}
\hline Day & Empty tube & MTA & CPM \\
\hline 7 & $133.7 \pm 15.1$ & $120.0 \pm 5.3$ & $145.0 \pm 10.9$ \\
14 & $120.6 \pm 19.5$ & $135.7 \pm 8.0$ & $129.0 \pm 21.0$ \\
30 & $13.8 \pm 0.3$ & $40.2 \pm 0.3$ & $39.8 \pm 0.4$ \\
\hline
\end{tabular}

MTA: mineral trioxide aggregate; CPM: modified Portland cement. Data are expressed as mean \pm standard deviation.

\section{DISCUSSION}

The growing technological evolution and continuous introduction of endodontic materials for different applications make the evaluation of the biological properties of these new products a mandatory condition. Materials must not have deleterious effect when in contact with tissues before they are marketed and 
used routinely in the clinic (14). Following ISO/6876 and 10993-5 regulations (15), in vitro cytotoxicity tests, such as tissue and cell culture assays, are important to provide initial evidence in the study of dental materials, and are critical in order to identify those components exercising cytotoxic effects. However, these tests lack the interaction of the material with cells in the tissue, and those who are attracted to the site reaction.

As a second step, it is proposed the in vivo im-

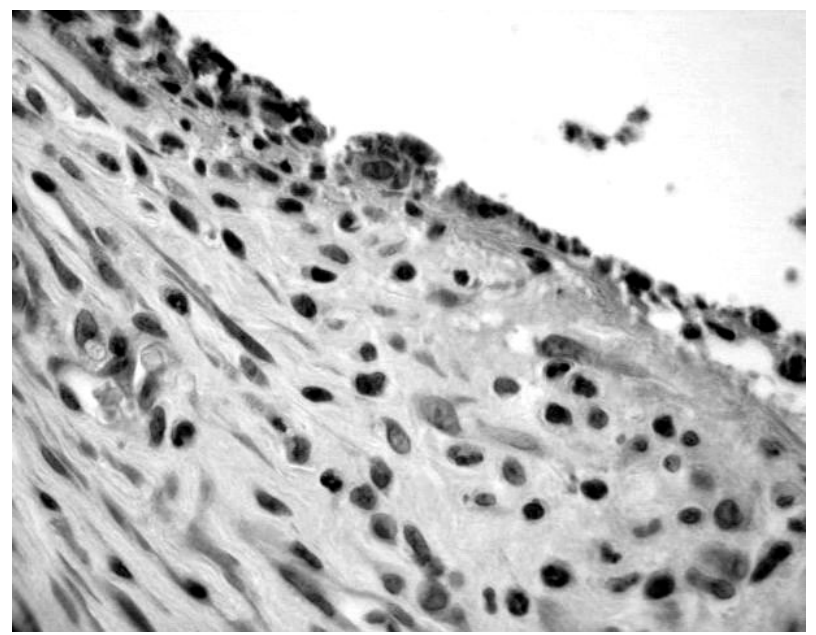

Figure 1. Tissue response to MPC 7 days after implantation showing inflammatory cells with numerous eosinophils. Luna stain ( $\times 600$ magnification).

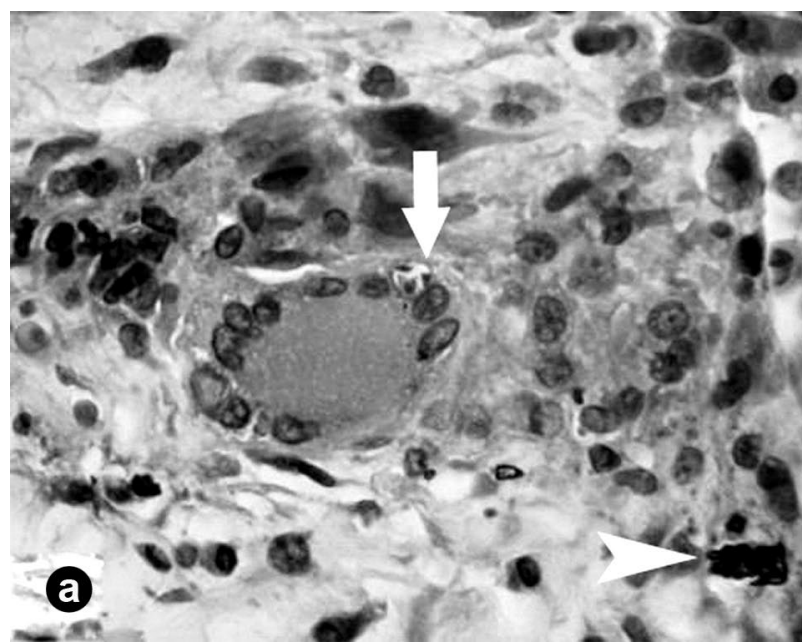

plantation of materials in laboratory animals $(16,17)$ which provides much more information about the inflammatory and immune responses developed by the test material (18). It is clear that one cannot extrapolate data to humans based on the results of experiments on animals. However, the introduction of different materials in the subcutaneous cellular tissue or bone from small laboratory animals are widely regarded as valid procedures for the study of their biological properties (16-18). Taking into account that CPM is already in the market, and there are none studies on its biocompatibility properties, as a first step we decided to test them in cellular subcutaneous tissue because it is a simple, fast and economical method. MTA is used in endodontics to seal natural, pathologic or iatrogenic communications between the root canal system and periapical tissues. The biocompatibility of this material has been reported in animals and humans (3). There are many studies comparing the biocompatibility of calcium hydroxide, MTA and Portland cement. There are also some studies that compare them to other root-end filling materials commonly used in endodontics $(9-11,19)$.

The present study evaluated the inflammatory reaction of the cellular subcutaneous tissue of rats to silicone tubes filled with MTA or CPM. The materials were placed into tubes in order to simulate clinical situation. Different kinds of tubes have been used: dentine tubes (9), polytetrafluoroethylene tubes (19),

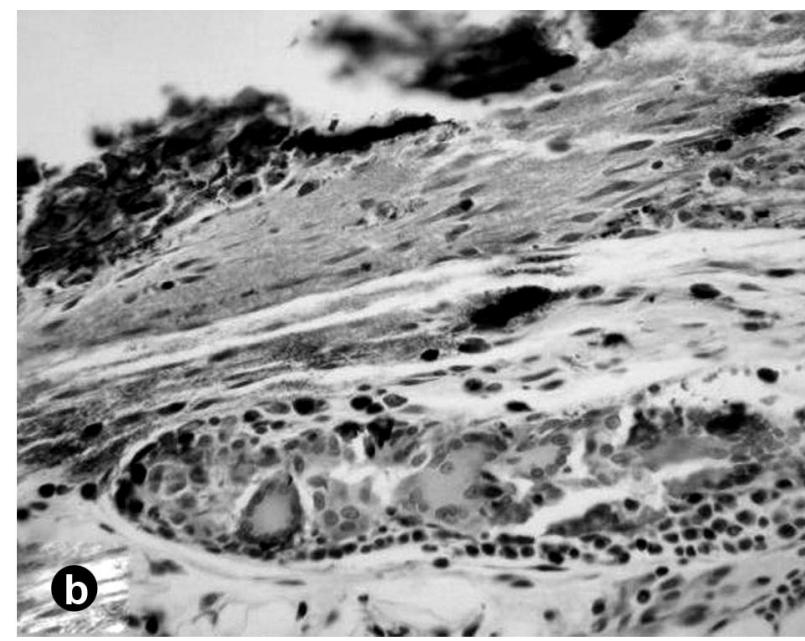

Figure 2. Tissue response to MTA. A(7 days): A foreign-body giant cell can be seen engulfing particles of MTA(arrow) at tissue-material interface (arrowhead). Hematoxylin-eosin ( $\times 600$ magnification). B (14 days): A granulomatous tissue containing many inflammatory cells and numerous macrophages and multinucleate foreign body giant cells. Necrotic tissue was observed in close contact with the material. Hematoxylin and eosin $(\times 250$ magnification $)$. 
polystyrene tubes (11), polypropylene tubes (19), and silicone tubes (7). Like others, silicone tubes are well tolerated by tissues, without toxicity but they have the advantage of being easier to process histologically than polytetrafluoroethylene or polystyrene ones.

According to the present results, there is a different tissue response to CPM and MTA. The data on MTA biocompatibility matches that from other authors in previous studies $(9,11)$. In those studies, a moderate to severe inflammatory reaction with the presence of necrosis, macrophages and giant cells was reported at days 7 and 15. Over longer periods, the inflammation diminished and a thin fibrous capsule was seen. To the best of our knowledge, there is no other study evaluating the biocompatibility of CPM, but data of a similar material, Portland cement (PC), are available. Campos Quintana et al. (20) evaluated the biocompatibility of PC, implanted subcutaneously inside polypropylene tubes in rats. No differences were found between control group (polypropylene tube empty) and experimental group (tube filled with PC). In both groups, a mild to moderate inflammatory reaction was observed. It is important to mention that mast cells and eosinophils were found in the inflammatory infiltrate of the PC group. These results match our data from the specimens in the CPM group. Another study (10) evaluated the reaction of the subcutaneous tissue of rats after 7 and 30 days, implanted with dentine tubes filled with MTA, calcium hydroxide or PC. The authors found similar results for the 3 materials in specimens stained with hematoxylin and eosin. After 7 days, mild to moderate inflammatory reaction with some giant cells was observed in all groups, while after 30 days, a fibrous connective tissue was found in contact with the materials, with a mild inflammatory reaction and scarce giant cells. In this study, the presence of eosinophils in the PC group was not reported.

Holland et al. (9) reported that the mechanism of action of MTA is similar to that reported for calcium hydroxide, producing calcite crystals. This mechanism might explain the reported reaction, with necrosis and multinucleate giant cells. However, we were not able to explain the presence of eosinophils in the inflammatory infiltrate in the CPM group. Further studies are required to explain the eosinophilia in the infiltrate and to establish its clinical importance.

Considering that rat neutrophils are particularly eosinophilic when stained with hematoxylin and eosin, Luna's stain was done in new histological sections to confirm the obtained results. This staining method produces a distinctive red stain and is specific for eosinophils because it stains only eosinophilic granules, Charcott-Leyden crystals and erythrocytes (13).

According to findings of the present study, there is a different early tissue response to MTA and CPM. Although both materials induced the production of a chronic inflammatory infiltrate, necrosis and multinucleated foreign body giant cells were predominant at days 7 and 14 in the MTA group, while in the CPM group numerous eosinophils were seen at all the observational periods. Further research is necessary to confirm these results and to understand the clinical significance of the persistence of eosinophilia. Future studies will allow us to evaluate whether eosinophilia can still be seen at longer periods of observation than those used in the present study. An ongoing "usage test" is currently evaluating the periapical tissue reaction to the materials in rats, and the results will soon be published.

\section{RESUMO}

O propósito deste estudo foi comparar a biocompatibilidade do cimento Portland modificado (CPM) com agregado de trióxido mineral (MTA) no subcutâneo de um modelo murino. Foram usados 24 ratos Wistar macho. No tecido subcutâneo dorsal de cada animal se colocaram 3 tubos de silicone. Um contendo MTA, outro CPM e o último vazio. Os animais foram sacrificados em 3 grupos de 8 aos 7, 14 e 30 dias. As amostras se fixaram em formol e se coloriram com hematoxilina - eosina, Masson e Luna. No dia 7 os tubos vazios mostraram uma leve infiltração de células inflamatórias. No grupo CPM, se observou um infiltrado inflamatório com alguns eosinófilos e tecido conectivo imaturo. O grupo MTA mostrou um infiltrado similar sem eosinófilos e abundante necrose de tecido e numerosas células gigantes multinucleadas do tipo corpo estranho. Ao dia 14, o infiltrado crônico com eosinófilos persistiu em contato com CPM. No grupo MTA, a necrose e células multinucleadas afastadas ainda se podiam observar. Ao dia 30, os 3 grupos mostraram tecido fibroso maduro. Estes resultados mostram uma resposta diferente aos materiais avaliados no presente estudo. Apesar do que MTA e CPM causaram um infiltrado crônico, no grupo MTA predominou a necrose e as células gigantes, enquanto isso, no grupo CPM se observaram grandes quantidades de eosinófilos.

\section{ACKNOWLEDGEMENTS}

This study received financial support from a scientific grant from the Asociación Odontológica Argentina.

\section{REFERENCES}

1. Mc Donald NJ, Torabinejad M. Endodontic Surgery in: Walton 
RE, Torabinejad M. Principles and Practice of Endodontics. 3rd ed. Philadelphia: WB Saunders Co; 2002. p. 424-444.

2. Ozbas H, Yaltirik MK, Bilgic B, Issever H. Reactions of connective tissue to compomers, composite and amalgam root-end filling materials. Int Endod J 2003;36:281-287.

3. Economides N, Pantelidou O, Kokkas A, Tziafas D. Short-term periradicular tissue response to mineral trioxide aggregate (MTA) as root-end filling material. Int Endod J 2003;36:44-48.

4. Camilleri J, Pitt Ford TR. Mineral trioxide aggregate: a review of the constituents and biological properties of the material. Int Endod J 2006;39:747-754.

5. Torabinejad M, Hong CU, Mc Donald F, Pitt Ford TR. Physical and chemical properties of a new root end filling material. J Endod 1995;21:349-353.

6. Camilleri J, Montesin FE, Di Silvio L, Pitt Ford TR. The chemical constitution and biocompatibility of accelerated Portland cement for endodontic use. Int Endod J 2005;38:834-842.

7. Zmener O. Tissue response to a new methacrylate - based root canal sealer: Preliminary observations in the subcutaneous connective tissue of rats. J Endod 2004;30:348-351.

8. Biondi AM, Cortese SG, Ortolani A, Benchuya C, Tedesco M Pulpotomías en molares primarios. Evaluación clínico-radiográfica de formocresol o trióxido mineral agregado. Rev Fac Odontol (UBA) 2008;23:13-17.

9. Holland R, De Souza V, Nery MJ, Faraco Junior IM, Bernabe $\mathrm{PF}$, Otoboni Filho JA, et al.. Reaction of rat connective tissue to implanted dentin tubes filled with mineral trioxide aggregate or calcium hydroxide. J Endod 1999;25:161-166.

10. Holland R, De Souza V, Nery MJ, Faraco Junior IM, Bernabe PF, Otoboni Filho JA, et al.. Reaction of rat connective tissue to im- planted dentin tube filled with mineral trioxide aggregate, Portland cement or calcium hydroxide. Braz Dent J 2001;12:3-8

11. Yaltirik M, Ozbas H, Bilgic B, Issever H. Reactions of connective tissue to mineral trioxide aggregate and amalgam. J Endod 2004;30:95-99.

12. Canadian Council on Animal Care. Guide to the care and use of experimental animals. 2 vols. Ottawa, Ont.: CCAC, 1980-1984.

13. Luna LG. Manual of Histologic Staining Methods for the AFIP 3rd ed. New York: Graw-Hill; 1968. p 162-163.

14. Lawrence WH, Malik M, Autian J. Development of a toxicity program for dental materials and products. J Biomed Mat Res 1974;8:11-34.

15. Camps J, About I. Cytotoxicity of endodontic sealers: a new method. J Endod 2003;29:583-586.

16. Federation Dentaire Internationale. Recommended standard practices for biological evaluation of dental materials. Int Dent $J$ 1980;30:140-188.

17. International Standards Organization. ISO 10993-6(F)-07-15. Biological evaluation of medical devices. Part 6. Tests for local effects after implantation. CP56. CH1211, Geneva;1994. p 1-8.

18. Watson A, Paterson, RC. Initial biological testing of root canal sealing materials. A critical review. J Dent 1992;20:259-265.

19. Saidon J, He J, Zhu Q, Safavi K, Spangberg LS. Cell and tissue reactions to mineral trioxide aggregate and Portland cement. Oral Surg Oral Med Oral Pathol Oral Radiol Endod 2003;95:483-489.

20. Campos QI, Llamosas HE, Morales LR. Evaluación de la biocompatibilidad del cemento Portland implantado en tejido conectivo subepitelial de ratas. Rev Asoc Dent Mex 2003;60:45-51.

Accepted April 15, 2009 